\title{
Studi Mengenai Gambaran Subjective Well-Being pada Ibu Pekerja Selama Masa Pandemi Covid-19
}

\section{Yulia Putri Pratiwi*}

Prodi Ilmu Psikologi, Fakultas Psikologi, Universitas Islam Bandung, Indonesia.

\author{
*Yuliappratiwi30@gmail.com
}

\begin{abstract}
The Covid-19 pandemic has had a significant impact on the subjective well-being of working mothers who work from home. The Covid-19 pandemic situation provides complex conditions for working mothers who work from home, then this situation causing distress, where mothers have to monitor and control their children's schoolwork, household tasks, and are required to work remotely from home. This has a psychological impact on a mother, one of which is subjective well-being. The purpose of this study is to see how the subjective well-being of a working mother who works from home during the Covid-19 pandemic in Bandung City. This study uses a qualitative method with a quantitative approach. The sample in this study was 300 people, using purposive sampling technique. Measurement of subjective well-being is obtained through two measuring tools from Diener, namely the Satisfaction With Life Scale (SWLS) which has been adapted by Yusak Novanto and the Scale of Positive and Negative Experience (SPANE). The results of the two measuring tools show that $70 \%$ of the subjective well-being of working mothers who work from home during the Covid-19 pandemic in Bandung City is lower.
\end{abstract}

Keywords: Working Mother Work From Home, Subjective Well-Being, Covid-19.

\begin{abstract}
Abstrak. Pandemi Covid-19 memiliki dampak yang cukup besar bagi subjective well-being pada ibu pekerja yang work from home. Keadaan pandemi Covid-19 memberikan kondisi yang kompleks pada ibu pekerja yang work from home sehingga menyebabkan distress, dimana ibu harus memantau dan mengontrol tugas-tugas sekolah anak, tugas rumah tangga, serta diharuskan bekerja secara jarak jauh dari rumah. Hal memberikan dampak psikologis bagi seorang ibu salah satunya adalah subjective well-being. Tujuan dari penelitian ini adalah melihat bagaimana gambaran subjective well-being seorang ibu pekerja work from home selama masa pandemi Covid-19 di Kota Bandung. Penelitian ini menggunakan metode deskriptif dengan pendekatan kuantitatif. Sampel penelitian ini adalah 300 orang, dengan menggunakan teknik purposive sampling. Pengukuran subjective well-being didapatkan melalui 2 alat ukur dari Diener, yaitu Satisfaction With Life Scale (SWLS) yang telah diadaptasi oleh Yusak Novanto dan Scale of Positive and Negative Experience (SPANE). Hasil dari dua alat ukur tersebut adalah $70 \%$ subjective well-being ibu pekerja work from home selama masa pandemi Covid-19 di Kota Bandung adalah rendah.
\end{abstract}

Kata Kunci: Ibu Pekerja Work From Home, Subjective Well-Being, Covid-19. 


\section{A. Pendahuluan}

Pada akhir tahun 2019 di bulan Desember, tepatnya di kota Wuhan negara China terjadi suatu wabah penyakit yang disebabkan oleh virus Severe Acute Respiratory Syndrome Coronavirus2 (SARS-CoV-2) atau yang disebut dengan Coronavirus Disease (COVID-19). Negara Indonesia sendiri termasuk salah satu dari 222 negara yang terkena penyakit Covid-19 dan berada pada peringkat ke-19 di dunia dengan kasus terbanyak yaitu 1.583 .182 orang, dengan kematian 42.906 orang (1). Dengan adanya wabah pandemi Covid-19, hampir di semua negara yang terkena wabah tersebut melakukan lockdown pada tahun 2020, dan salah satunya adalah negara Indonesia (2). Sampai saat ini tahun 2021, Negara Indonesia sendiri masih belum membuka tempat secara terbuka dan masih ada batasan pengunjung untuk tempat tertentu salah satunya kantor, tempat wisata, pusat perbelanjaan, rumah makan, tempat ibadah, sedangkan tempat yang masih ditutup adalah sekolah dan perguruan tinggi. Salah satu dampak PSBB karena pandemi Covid-19 tersebut menyebabkan sektor pendidikann yang dilaksanakan luring menjadi daring, serta pekerjaan yang seharusnya masuk secara tatap muka diganti menjadi dengan work from home. Work from home merupakan bagian dari konsep telecommuting yaitu bekerja jarak jauh (3). Menurut Konradt, Schmook, dan Malecke (2000), bahwa bekerja jarak jauh dimaksudkan sebagai cara bekerja dalam sebuah organisasi yang dilaksanakan sebagian atau seluruhnya di luar kantor konvensional dengan bantuan layanan telekomunikasi dan informasi (4).

Dari keaadaan work from home pada masa pandemi covid-19, banyak orang tua yang harus bekerja sambil memiliki peran dan tugas lain terutama bagi seorang ibu pekerja yang work from home, mereka harus menjadi seorang ibu rumah tangga dan menjadi guru bagi anak-anaknya. Sesuai dengan hasil survei yang dilakukan oleh Komnas Perempuan, terdapat 96\% dari 2.285 orang melaporkan bahwa beban pekerjaan rumah tangga semakin banyak terutama wanita bekerja dua kali lipat dari pada pria (5). Terdapat penelitian yang menyatakan adanya tugas tambahan pada ibu yaitu Limbers di Amerika Serikat, saat masa pandemi Covid19 seorang ibu jadi memiliki banyak peran dan situasi yang tidak proposional karena memiliki beberapa tuntutan yang lebih banyak dari biasanya seperti pekerjaan rumah tangga, bekerja kantoran, mengasuh anak, menjadi seorang guru karena mengajari anak, dan melayani suami (6). Penelitian lain yaitu Wulandari di Indonesia juga menyatakan bahwa, seorang wanita yang sudah memiliki rumah tangga dan anak mempunyai tuntutan yang lebih terutama di dalam situasi pandemi Covid-19, dimana mereka harus mendampingi anaknya untuk melakukan aktivitas pendidikan secara daring, terlebih lagi jika usia anak belum memungkinkan untuk dapat menggunakan media seperti laptop ataupun handphone (7).

Menjadi seorang Ibu tentunya bukanlah situasi yang mudah, terutama dalam menjalani peran sebagai ibu di tengah masa pandemi Covid-19 dihadapkan dalam menyeimbangkan antara tanggung jawab tugas sebagai seorang pekerja dari rumah dan menjalankan kewajiban sebagai ibu rumah tangga. Terutama saat masa pademi Covid-19, saat ini permasalahan banyak terjadi saat ibu menjalankan tugas-tugasnya dirumah. Wardani dan Ayriza (2020) menyatakan bahwa orang tua mengalami banyak kendala dalam tugas-tugasnya saat ia harus menjadi seorang guru di pembelajaran daring anaknya. Kendala yang dijelaskan dalam penelitiannya adalah seperti orang tua harus dapat membagi waktu dengan pekerjaan terutama ketika pekerjaan dan kelas daring anaknya memiliki waktu yang bersamaan, orang tua yang mengalami kesulitan dalam mengoperasikan gadget, sulit mengakses web pendidikan anak, sulit memahami materi anak, jangkauan layanan internet yang minim serta orang tua menjadi tidak sabar mendampingi anak (8). Menurut Huebener (2021) menggabungkan pekerjaan dari rumah dengan menjaga anak serta mendampingi sekolah di rumah menjadi sebuah beban yang luar biasa bagi orang tua yang bekerja (9). Sebuah kendala yang terjadi dalam hidup dapat menjadi sebuah stressor yang menyebabkan tekanan bagi diri individu. Diener dan Pavot (2004) menjelaskan bahwa keadaan seseorang yang tertekan berhubungan erat dengan wellbeing atau kebahagiaan seseorang (10).

Secara konseptual, salah satu konsep psikologi yang membahas kebahagiaan dari kepuasaan hidup adalah teori subjective well-being dari Diener (1984). Subjective well-being menurut Diener (1984) merupakan evaluasi subjektif seseorang terhadap hidupnya baik secara 
kognitif dan afektif, yang ditandai dengan tingginya kepuasan hidup dan perasaan positif serta rendahnya perasaan negatif (11). Diener (1985) menyatakan bahwa individu yang puas dengan kondisi kehidupannya, sering mengalami hal positif, dan jarang mengalami emosi negatif adalah individu yang merasakan "happiness" atau kebahagiaan dalam hidupnya (10). Teori subjective well-being dari Diener (1984) menyatakan bahwa terdapat evaluasi akan kejadian yang telah terjadi atau dialami dalam kehidupan yang melibatkan proses kognitif dan afektif (11). Dalam hal evaluasi secara kognitif mencakup kepuasan hidup yang terdiri dari kepuasan hidup secara keseluruhan dan kepuasan hidup dalam ranah yang khusus, seperti pendapatan, keluarga dan relasi sosial, pekerjaan, dan kesehatan. Sedangkan evaluasi secara afektif mencakup perasaan positif misalnya perasaan senang, puas, nyaman, gembira dan reaksi emosional negatif misalnya perasaan marah, sedih, buruk, tidak nyaman, serta takut.

Dengan berbagai kondisi yang terjadi pada ibu pekerja yang work from home selama masa Pandemi Covid-19, seorang ibu memiliki evaluasi atau penilaian atas kondisi dan situasinya tersebut dimana beberapa ibu merasakan kehidupan yang tidak cukup puas, walaupun disatu sisi ada beberapa ibu lainnya yang memiliki kepuasan yang cukup atas kehidupannya saat work from home di masa pandemi Covid-19. Hal ini ditunjang oleh penelitian pra-survey yang dilakukan oleh penulis pada 69 orang ibu yang bekerja secara work from home. Beberapa orang ibu menjelaskan bahwa waktu mereka menjadi terbagi akan banyak hal, dalam waktu yang bersamaan mereka harus menyelesaikan pekerjaan rumah, menyelesaikan pekerjaan kantor, membantu kegiatan sekolah seperti tugas ataupun ujian anak. Selain itu permasalahan yang lebih sering terjadi adalah ketika waktu kegiatan daring sekolah anak bersamaan dengan jadwal pekerjaan di kantor. Selepas dari permasalahan yang ada seperti bertambahnya tugas-tugas dirumah dimana ibu juga dituntut untuk menyelesaikan pekerjaannya sebagai seorang pekerja kantoran, tetapi para ibu tetap merasakan rasa senang bahwa setidaknya mereka dapat berkumpul bersama keluarga kecilnya (12). Berdasarkan kondisi yang terjadi, terdapat beberapa ibu yang menyatakan bahwa dari segala kondisi yang dialami saat ini mereka masih bersyukur dan merasakan rasa nikmat ketika mereka tetap dapat berkumpul bersama dimana artinya ketika mereka merasakan rasa negatif mereka merubahnya kedalam perasaan positif dalam bentuk syukur dan nikmat, dari hal ini mereka dapat membangun sebuah hubungan yang lebih erat, melakukan komunikasi tatap muka yang intens baik dengan anak maupun suami walaupun suami tetap melakukan pekerjaannya secara work from home. Berdasarkan perasaan seorang ibu bahwa hal ini termasuk dalam mengontrol emosi, Khairiyah menyatakan bahwa regulasi emosi merupakan salah satu aspek yang penting bagi seorang ibu yang bekerja untuk menghadapi stres, serta akan berperan dalam meningkatkan kesejahteraan psikologis mereka, dimana regulasi emosi yang tepat dapat memberikan ketenangan sehingga berpengaruh dalam mengambil sebuah keputusan yang sesuai (13).

Perubahan yang mendadak dan tekanan yang dihadapi oleh ibu pekerja yang work from home, baik secara internal maupun eksternal dapat memicu emosi yang positif maupun negatif. Keadaan dan kondisi tersebut membuat seorang ibu menjadi stres karena dihadapkan pada kegiatan yang beragam dan multitasking $(14,15)$. Seorang peneliti dari negara Italia yaitu Spinelli (2020) menjelaskan bahwa Ibu juga mendapatkan dampak secara psikis karena perubahan hidup yang terjadi selama masa pandemi Covid-19, dimana situasi tersebut menyebabkan risiko tingkat stres jadi lebih tinggi pada ibu karena tugas yang semakin berat di kondisi saat pandemi Covid-19 dimana hal itu memberikan emosi yang negatif pada ibu (16). Di negara Indonesia, terjadi fenomena bahwa ibu merasakan rasa stres yang jauh lebih tinggi saat pandemi Covid-19. Hal ini didukung oleh berita yang dimuat dalam CNN Indonesia, bahwa 56\% ibu di Indonesia mengaku stres dan mengalami gejala kecemasan, sulit tidur, serta mudah marah (CNN, 2020). Penelitian-penelitian sebelumnya menyatakan bahwa terjadi penurunan subjective well-being pada ibu pekerja yang work from home. Salah satunya di negara Germany, seorang peneliti yaitu Möhring (2020) mendapatkan hasil bahwa subjective well-being memiliki penurunan dimasa pandemi, penurunan ini paling menonjol dirasakan oleh ibu yang bekerja akibat menurunnya kepuasan terhadap keluarga dan kepuasan kerja (18).. 
Berdasarkan latar belakang yang telah diuraikan, maka perumusan masalah dalam penelitian ini adalah "Studi Mengenai Gambaran Subjective Well-Being Pada Ibu Pekerja Selama Masa Pandemi Covid-19" dengan studi pada ibu pekerja work from home di Kota Bandung. Sedangkan tujuan dari penelitian ini adalah untuk mendapatkan gambaran subjective well-being pada ibu pekerja work from home di Kota Bandung selama masa pandemi Covid-19

\section{B. Metodologi Penelitian}

Peneliti menggunakan metode deskriptif dengan menggunakan pendekatan kuantitatif. Populasi yang dipilih dalam penelitian ini adalah ibu pekerja work from home di Kota Bandung. Teknik sampling dilakukan dengan cara purposive sampling, dan diperoleh jumlah sampel penelitian sebanyak 300 ibu pekerja work from home. Teknik pengumpulan data yang digunakan dalam penelitian ini adalah kuesioner. Adapun teknik analisis data yang digunakan dalam penelitian ini adalah teknis analisis deskriptif statistik.

\section{Hasil Penelitian dan Pembahasan}

\section{Gambaran Subjective Well-Being Komponen Kognitif dan Afektif}

Tabel 1. Data Komponen Kognitif

\begin{tabular}{ccc}
\hline Kategori & Frekuensi & Persentase \\
\hline Kognitif Rendah & 111 & $37,00 \%$ \\
\hline Kognitif Tinggi & 189 & $63,00 \%$ \\
\hline Total & 300 & $100,00 \%$
\end{tabular}

Berdasarkan tabel 1 dapat disimpulkan bahwa dari 300 responden terdapat sebagian besar yaitu 189 orang dengan persentase $63 \%$ memiliki kepuasan hidup yang tinggi, sedangkan sisanya yaitu 111 orang dengan persentase $37 \%$ memiliki kepuasan hidup yang rendah.

Tabel 2. Data Komponen Affect Balance (SPANE-B)

\begin{tabular}{ccc}
\hline Kategori & Frekuensi & Persentase \\
\hline Afektif Negatif & 170 & $56,67 \%$ \\
\hline Afektif Positif & 130 & $43,33 \%$ \\
\hline Total & 300 & $100,00 \%$
\end{tabular}

Berdasarkan tabel 2 dapat disimpulkan bahwa secara keseluruhan komponen afektif responden memiliki afek yang negative yaitu dengan jumlah 170 orang dan memiliki persentase sebesar $56,67 \%$, sedangkan sisanya yaitu 130 orang dengan persentase $43,33 \%$ memiliki afek yang positif.

\section{Hasil Data Deskriptif Subjective Well-Being}

Tabel 3. Data Deskriptif Subjective Well-Being pada Ibu yang WFH

\begin{tabular}{ccc}
\hline Kategori & Frekuensi & Persentase \\
\hline Subjective Well-Being Rendah & 210 & $70 \%$ \\
\hline Subjective Well-Being Tinggi & 90 & $30 \%$ \\
\hline Total & 300 & $100 \%$ \\
\hline
\end{tabular}

Berdasarkan tabel 3 dapat disimpulkan bahwa secara keseluruhan subjective well-being pada ibu yang work from home di Kota Bandung memiliki kategori yang rendah yaitu dengan frekuensi 210 orang atau dengan persentase sebesar $70 \%$ dan sisanya memiliki subjective wellbeing yang tinggi dengan total 90 orang atau persentase sebesar $30 \%$.

Hasil dari penelitian terlihat bahwa data tersebut menunjukkan rendahnya tingkat subjective well-being pada ibu yang work ftom home selama masa pandemi Covid-19 di Kota Bandung sebesar $70 \%$ dengan frekuensi 210 orang. Diener (dalam Eid \& Larsen, 2008) menyatakan bahwa seseorang yang memiliki subjective well being yang tinggi yaitu disaat seseorang tersebut memiliki kepuasan hidup yang tinggi atau sangat puas dan mengalami 
kehidupan yang penuh dengan perasaan positif atau rasa senang, serta tidak sering merasakan rasa negatif atau rasa sedih dan rasa yang tidak menyenangkan didalam diri. Disaat seseorang tersebut lebih sering merasakan perasaan negatif serta memiliki rasa kepuasan hidup rendah dan tidak sesuai dengan harapan artinya subjective well-being seseorang tersebut rendah, dimana mereka lebih sering memiliki perasaan yang tidak menyenangkan dalam dirinya dan sedikit merasakan adanya ketidakbahagiaan dan ketidakpuasan didalam hidupnya. Analisa data yang dilakukan dapat diartikan bahwa subjective well-being rendah pada ibu yang work from home didapatkan karena ada faktor lain yang mempengaruhi serta dikarenakan kondisi masa pandemi Covid-19 yang menjadikan ibu memiliki beban yang lebih berat didalam rumah, dimana ibu work from home memiliki banyak peran tambahan. Adapun aspek yang mendukung tinggi dan rendahnya subjective well-bein yaitu aspek kognitif serta aspek afektif.

Aspek pertama adalah kognitif dimana aspek tersebut membahas mengenai komponen life satisfaction. Dalam aspek tersebut seseorang dikatakan sejahtera jika ia merasa puas dengan kehidupannya dengan cara mengevaluasi terhadap kepuasan hidup yang didapatkan dan dialaminya (11). Pada tabel 1 dapat diketahui bahwa hasil dari aspek kognitif mengenai life satisfaction ibu yang work from home adalah tinggi dengan besar persentase $63 \%$ sedangkan sisanya yaitu $37 \%$ rendah. Dari data life satisfaction yang tinggi tersebut dapat diartikan bahwa ibu yang work from home (WFH) di masa pandemi Covid-19 mengevaluasi kehidupannya dan merasakan adanya rasa puas dalam hidupnya. Seseorang yang memiliki kepuasan hidup dengan kategori tinggi akan membuat mereka memandang hidup menjadi lebih positif (19). Selepas dari permasalahan yang terjadi seorang ibu work from home, mereka tetap merasakan rasa senang bahwa setidaknya kondisi pandemi Covid-19 memiliki hal yang positif salah satunya mereka tetap bisa bermain dengan anak-anak dan lebih memiliki banyak waktu dengan keluarga. Dari data yang didapatkan dapat dianalisa bahwa sebagian besar ibu yang menjalankan WFH di masa pandemi Covid-19 merasakan bahwa mereka sedikit setuju atas pencapaian yang dituju selama masa pandemi Covid-19. Artinya, subjek sudah dapat memenuhi tujuan yang diinginkannya walaupun belum sepenuhnya dicapai. Sedangkan pada ibu work from home yang memiliki kepuasan hidup rendah dapat diartikan bahwa mereka mengevaluasi kehidupannya dan merasakan ketidakpuasan dalam hidupnya selama masa pandemi Covid-19. Kepuasan hidup rendah yang dirasakan seseorang akan membuat mereka memandang hidup menjadi lebih negatif (19). Mereka merasa bahwa kehidupannya tidak sesuai dengan keidealan yang diinginkannya, hal tersebut menandakan adanya perasaan dimana seorang ibu yang WFH belum dapat menerima kehidupannya saat ini di masa pandemi Covid-19. Hal ini sesuai dengan teori dari Diener (1984), bahwa kepuasan hidup yang rendah akan membuat evaluasi seseorang dalam kehidupannya cenderung negatif dan merasakan rasa tidak bahagia (11). Berdasarkan analisa data pada skor responden, diketahui bahwa ibu WFH yang memiliki kepuasan hidup rendah dikarenakan mereka merasakan kondisi kehidupan yang dijalaninya selama masa pandemi Covid-19 kurang baik, serta mereka tidak ingin menjalani kehidupan dengan keburukan yang terjadi selama masa pandemi Covid-19.

Terdapat aspek lainnya yaitu aspek afektif dimana subjective well-being diukur berdasarkan frekuensi komponen emosi positif dan emosi negatif dari pengalamanpengalaman dasar dalam suatu peristiwa yang terjadi di dalam hidup seseorang (11). Dari data yang didapatkan yaitu pada tabel 2 diketahui affect balance (SPANE-B) pada ibu yang work from home adalah rendah yaitu sebesar 56,67\% merasakan perasaan negative dan 43,33\% merasakan perasaan positif. Diener, Scollon dan Lucas (2005) menyatakan bahwa subjective well-being ditentukan berdasarkan seberapa sering seseorang merasakan suatu emosi, bukan dari seberapa kuatnya emosi tersebut. Subjective well-being dikatakan tinggi apabila seseorang sering mengalami perasaan positif dan jarang mengalami perasaan negatif (Diener, 2005). Berdasarkan hasil analisa skor responden dari kuisioner yang ada, diketahui mengapa subjective well-being ibu yang work from home rendah dan lebih dominan pada perasaan negatif, dari data yang didapatkan menjelaskan bahwa ibu WFH lebih dominan pada perasaan negatif karena adanya rasa yang tidak nyaman, merasa hal-hal buruk sering terjadi, perasaan sedih yang cukup sering terjadi, dan perasaan takut selama masa pandemi Covid-19. Hal ini terjadi karena berbagai faktor yang mucul, salah satunya penelitian yang menyatakan ibu 
memiliki aspek afektif yang rendah karena adanya jadwal bentrok antara pekerjaan yang orang tua miliki dan kegiatan sekolah pada anak dan mengakibatkan konflik, dan rasa stres pada ibu (9). Selain itu adanya penelitian lain yang menyatakan bahwa, perasaan negatif seorang ibu di masa pandemi Covid-19 cenderung meningkat dikarenakan berbagai faktor seperti beban pekerjaan pada seorang ibu lebih meningkat terutama pada ibu yang memiliki perkejaan jarak jauh $(9,20,21)$. Terdapat penelitian lain yang menyebutkan bahwa ibu yang work from home mengalami perasaan stres serta kondisi emosi yang lebih mengarah ke arah negatif seperti perasaan marah, kesal, sedih, menangis, dan tidak puas atas kehidupan yang dijalani nya saat ini (6).

\section{Kesimpulan}

Berdasarkan hasil penelitian yang dilakukan mengenai gambaran subjective well-being pada ibu yang work from home selama masa pandemi Covid-19 di Kota Bandung, dapat disimpulkan bahwa:

1. Ibu yang work from home (WFH) selama masa pandemi Covid-19 di Kota Bandung memiliki life satisfaction yang tinggi dimana adanya perasaan yang puas atas kehidupan selama masa pandemi Covid-19. Hal ini menunjukkan bahwa mereka sudah mencapai tujuan yang ingin dicapai dan kehidupan yang ideal sesuai dengan yang diinginkannya.

2. Ibu yang work from home (WFH) selama masa pandemi Covid-19 di Kota Bandung memiliki Negative Affect yang lebih tinggi dibandingkan dengan Positive Affect. Hal ini menunjukkan bahwa ibu yang work from home merefleksikan reaksinya terhadap peristiwa-peristiwa yang tidak sesuai dengan keinginannya, dengan kata lain mereka lebih sering merasakan emosi yang tidak menyenangkan dalam kehidupannya.

3. Dari hasil data yang ditemukan, dapat diketahui bahwa subjective well-being ibu yang work from home (WFH) di Kota Bandung memiliki subjective well-being yang rendah. Artinya, bahwa mereka lebih sering memiliki perasaan yang tidak menyenangkan dalam dirinya dan merasakan adanya ketidakbahagiaan didalam hidupnya dimana mereka belum memiliki rasa kepuasan atas kehidupannya yang mereka jalani saat pandemi Covid-19.

\section{Acknowledge}

Dalam hal ini peneliti mengucapkan banyak rasa terima kasih kepada seluruh pihak yang sudah membantu dan berkontribusi dalam proses penelitian ini, sehingga peneltian ini dapat dilaksanakan dan diselesaikan

\section{Daftar Pustaka}

[1] Rizal JG. Update Corona Dunia 12 April: 10 Negara dengan Kasus Terbanyak 136 Juta Kasus Covid-19. Kompas.com [Internet]. 2021; Available from: https://www.kompas.com/tren/read/2021/04/12/112900465/update-corona-dunia-12-april10-negara-dengan-kasus-terbanyak-136-juta?page=all

[2] Aban R. Lockdown di Berbagai Negara Sepanjang Tahun 2020. Suara.com [Internet]. 2020; Available from: https://amp.suara.com/video/2020/12/31/110500/suasana-lockdown-diberbagai-negara-sepanjang-tahun-2020

[3] Mungkasa O. Bekerja dari Rumah (Working From Home/WFH): Menuju Tatanan Baru Era Pandemi COVID 19. J Perenc Pembang Indones J Dev Plan. 2020;4(2):126-50.

[4] Zacharry Glenn D. Variation in Job Performance Among Telecommuters. San Francisco State Universit; 2016.

[5] Alimatul Qibtiyah, Andy Yentriyani, Dwi Ayu Kartika, Mariana Amiruddin, Maria Ulfah Anshor, Marisna Yulianti, Rainy Maryke Hutabarat, Retty Ratnawati, Satyawanti Mashudi, Siti Nurwati Hodijah TSEI. Kajian Dinamika Perubahan di Dalam Rumah Tangga Selama Covid-19 di 34 Provinsi di Indonesia. Komnas Peremp. 2020;

[6] Limbers CA, McCollum C, Greenwood E. Physical activity moderates the association between parenting stress and quality of life in working mothers during the COVID-19 
pandemic. Ment Health Phys Act. 2020;19(July).

[7] Wulandari B, Veronika D, Kaloeti S. Subjective Well-Being in Working Mothers During the COVID-19 Pandemic: A Systematic Literature Review: Subjective Well-Being Pada Ibu yang Bekerja Di Masa Pandemi COVID-19: Studi Systematic Literature Review. 2021;1(1):1-9.

[8] Wardani A, Ayriza Y. Analisis Kendala Orang Tua dalam Mendampingi Anak Belajar di Rumah Pada Masa Pandemi Covid-19. J Obs J Pendidik Anak Usia Dini. 2020;5(1):772.

[9] Huebener M, Waights S, Spiess CK, Siegel NA, Wagner GG. Parental well-being in times of Covid-19 in Germany. Rev Econ Househ [Internet]. 2021;19(1):91-122. Available from: http://dx.doi.org/10.1007/s11150-020-09529-4

[10] Eid M, Larsen RJ. The Science of subjective well-being. Vol. 45, Choice Reviews Online. 2008. 45-5867-45-5867 p.

[11] Diener E. Diener_1984.pdf. Vol. 95, Psychological Bulletin. 1984. p. 542-75.

[12] Westrupp EM, Stokes MA, Fuller-tyszkiewicz M, Berkowitz TS, Capic T, Khor S, et al. Subjective wellbeing in parents during the COVID-19 pandemic in Australia. Aust N Z J Psychiatry. 2020;1-49.

[13] Khairiyah W. the Effect of Online Coumunication Quality on Subjective Well-Being Among Entrepreneures in Urban Area. Hasanuddin Econ Bus Rev. 2020;4(1):29.

[14] Thomeer MB, Reczek C, Umberson D. Gendered emotion work around physical health problems in mid- and later-life marriages. J Aging Stud [Internet]. 2015;32:12-22. Available from: http://dx.doi.org/10.1016/j.jaging.2014.12.001

[15] Hong F, Tarullo AR, Mercurio AE, Liu S, Cai Q, Malley-Morrison K. Childhood maltreatment and perceived stress in young adults: The role of emotion regulation strategies, self-efficacy, and resilience. Child Abus Negl [Internet]. 2018;86(October 2017):136-46. Available from: https://doi.org/10.1016/j.chiabu.2018.09.014

[16] Spinelli M, Lionetti F, Pastore M, Fasolo M. Parents' Stress and Children's Psychological Problems in Families Facing the COVID-19 Outbreak in Italy. Front Psychol. 2020;11(July):1-7.

[17] CNN T. 8 Bulan Pandemi, 56 Persen Ibu Rumah Tangga Alami Stres. CNN Indonesia [Internet]. 2020; Available from: https://www.cnnindonesia.com/gayahidup/20201111113804-255-568443/8-bulan-pandemi-56-persen-ibu-rumah-tangga-alamistres

[18] Möhring K, Naumann E, Reifenscheid M, Wenz A, Rettig T, Krieger U, et al. The COVID-19 pandemic and subjective well-being: longitudinal evidence on satisfaction with work and family. Eur Soc [Internet]. 2021;23(S1):S601-17. Available from: https://doi.org/10.1080/14616696.2020.1833066

[19] Diener E, Oishi S, Lucas RE. Subjective Well-Being: The Science of Happiness and Life Satisfaction. Oxford Handb Posit Psychol (2 Ed). 2005;(February 2019):1-16.

[20] Yamamura E, Tsustsui Y. The impact of closing schools on working from home during the COVID-19 pandemic: evidence using panel data from Japan. Rev Econ Househ [Internet]. 2021;19(1):41-60. Available from: http://dx.doi.org/10.1007/s11150-020-09536-5

[21] Paredes MR, Apaolaza V, Fernandez-Robin C, Hartmann P, Yañez-Martinez D. The impact of the COVID-19 pandemic on subjective mental well-being: The interplay of perceived threat, future anxiety and resilience. Pers Individ Dif [Internet]. 2021;170(July 2020):110455. Available from: https://doi.org/10.1016/j.paid.2020.110455 